\title{
Versão brasileira do Dizziness Handicap Inventory******
}

\author{
Brazilian version of the Dizziness Handicap Inventory
}

\author{
Ana Sílvia Oliveira de Castro* \\ Juliana Maria Gazzola** \\ Jamil Natour $* * *$ \\ Fernando Freitas Ganança****
}

*Fonoaudióloga. Mestre em Ciências pelo Programa de Pós-Graduação em Ciências da Reabilitação Neuro-Motora da Universidade Bandeirantes de São Paulo. Endereço para Correspondência: Av Jurucê, 511 - Apto. 94 - São Paulo SP - CEP 04080-012

(ana.silvia@ajato.com.br).

**Fisioterapeuta. Mestre em Ciências pelo Programa de Pós-Graduação em Otorrinolaringologia e Cirurgia de Cabeça e Pescoço da Universidade Federal de São Paulo - Escola Paulista de Medicina. Bolsista da Fundação de Amparo à Pesquisa do Estado de São Paulo.

***Médico. Professor Livre-docente da Disciplina de Reumatologia da Universidade Federal de São Paulo Escola Paulista de Medicina.

****Médico. Professor Doutor Afiliado da Disciplina de Otoneurologia da Universidade Federal de São Paulo - Escola Paulista de Medicina e do Programa de PósGraduação em Ciências da Reabilitação Neuro-Motora da Universidade Bandeirantes de São Paulo.

*****Trabalho Realizado no Setor de Reabilitação Vestibular da Disciplina de Otoneurologia - Universidade Federal de São Paulo - Escola Paulista de Medicina.

Artigo de Pesquisa

Artigo Submetido a Avaliação por Pares

Conflito de Interesse: não

Recebido em 28.03.2005.

Revisado em 17.05.2005; 09.08.2005; 12.09.2006; 29.11.2006.

Aceito para Publicação em 29.11.2006.

\section{Abstract}

Background: impact of dizziness on life quality (LQ). Aim: to adapt the Dizziness Handicap Inventory (DHI) for application in the Brazilian population; to assess its reproducibility; and to describe the results obtained in patients with chronic dizziness. Method: The DHI was initially applied in 45 patients with chronic dizziness and with a clinical diagnosis of vestibular syndrome. The application followed the stages of translation - from English to Portuguese - and linguistic adaptation, grammatical and idiomatic equivalence review and evaluation of its intra and inter-researchers reproducibility. Reproducibility was assessed by using the Wilcoxon Test for two dependent samples, $\mathrm{P}<0.05$. The questionnaire was applied on 250 patients with chronic vestibular syndrome in order to evaluate the impact of dizziness on LQ. Results: The Brazilian version of the DHI (Brazilian DHI) was well comprehended by the studied population and no statistically significant difference was found in the inter-researcher $(\mathrm{P}=0.418)$ and intra-researcher $(\mathrm{P}=0.244)$ reproducibility. All of the studied patients presented a loss in LQ due to dizziness. Aspects which were most affected were the physical ones, followed by, in a decreasing order, the functional and the emotional ones. Functional aspects were more compromised in older individuals. No association was verified between gender and the overall mean scores of the DHI and between gender and the mean scores of each aspect assessed by the DHI. Conclusion: the DHI was culturally adapted for application in the Brazilian population (Brazilian DHI). This instrument was considered to be a reliable tool to evaluate the impact of dizziness on LQ. Patients with chronic dizziness and with clinical diagnosis of vestibular syndrome presented a loss in LQ, due to this symptom. This loss was verified by the application of the Brazilian DHI. Physical aspects were the most compromised.

Key Words: Quality of Life; Dizziness; Vertigo; Vestibular Diseases.

\section{Resumo}

Tema: impacto da tontura na qualidade de vida (QV). Objetivo: adaptar culturalmente o Dizziness Handicap Inventory (DHI) para aplicação na população brasileira, avaliar sua reprodutibilidade e descrever os resultados obtidos à aplicação deste questionário em pacientes com tontura crônica. Método: o DHI foi aplicado, inicialmente, em 45 pacientes com tontura crônica e hipótese diagnóstica de síndrome vestibular, seguindo as etapas de tradução do idioma Inglês para o Português e adapatação lingüística, revisão da equivalência gramatical e idiomática, adaptação cultural e avaliação da reprodutividade intra e interpesquisadores. A avaliação da reprodutividade foi realizada por intermédio do teste de pesquisadores. A avaliação da reprodutividade foi realizada por intermédio do teste de Wilcoxon para duas amostras dependentes, $\mathrm{P}<0,05$. O instrumento foi aplicado para um total de 250 pacientes para avaliação do impacto da tontura na qualidade de vida de vestibulopatas crônicos. Resultados: a versão brasileira do DHI (DHI brasileiro) foi bem compreendida pelo população estudada. Não foi verificada diferença estatística significante à avaliação da reprodutibilidade inter-pesquisadores $(\mathrm{P}=$ $0,418)$ e intra-pesquisadores $(\mathrm{P}=0,244)$. Todos pacientes apresentaram prejuízo na $\mathrm{QV}$ e os aspectos físicos foram os mais prejudicados, seguidos em ordem decrescente pelos aspectos funcionais e emocionais. Os aspectos funcionais mostraram-se mais comprometidos em indivíduos mais velhos. Nenhuma associação foi verificada entre o gênero e as médias do escore total e de cada um dos aspectos avaliados pelo DHI. Conclusão: o DHI foi adaptado culturalmente para aplicação na população brasileira (DHI brasileiro), mostrando-se confiável para a avaliação da interferência da tontura na QV. Os pacientes com tontura crônica e hipótese diagnóstica de síndrome vestibular apresentaram prejuízo na QV devido a este sintoma, verificados à aplicação do DHI brasileiro. Os aspectos físicos foram os mais prejudicados. Palavras-Chave: Qualidade de Vida; Tontura; Vertigem; Doenças Vestibulares. 


\section{Introduction}

Dizziness is considered one of the most common clinical manifestations among adults, specially the elderly (Ganança, Caovilla, 1998a). It may be defined as a wrong perception, an illusion or a movement hallucination, a sensation of spatial disorientation of the rotatory type (vertigo), or not rotatory (instability, unbalance, fluctuation, oscillation, oscillopsia). Both types may be due to a vestibular disorder that can be assured by an otoneurological evaluation (Ganança, Caovilla, 1998b).

The dizzy patient usually reports mental concentration difficulty, loss of memory and fatigue. The physical insecurity generated by the chronic dizziness and by the lack of body balance may lead to irritability, loss of self-confidence, fear to go out alone, fear of a serious disease, sensation of being out of reality, besides anxiety, depression or panic (Yardley \& Putman, 1992; Ganança \& Caovilla, 1998a; Ganança et al., 2000). The vestibular system's disorders besides generating physical and emotional problems, may provoke incapacity for performing professional, social and domestic activities, worsening the quality of life (QOL) of these patients (Enloe \& Shields, 1997; Ganança et al., 2002).

The conventional tests that evaluate the vestibular system are not appropriate to demonstrate the psychological interference in the clinical picture and in the dizzy patient's suffering, as well as to evaluate the functional damages imposed by this symptom (Yardley, 1994). The necessity to evaluate these aspects in the dizzy patient leaded several researchers to elaborate questionnaires to evaluate the QOL of these patients.

Nowadays, the impact of the disease in the QOL of the individual has been more and more investigated (Fielder et al., 1996). The World Health Organization defines the QOL as the individual's perception of his position in life, in the context of the culture and values system in which he is inserted and in relation to his goals, expectations, patterns, and worries (World Health Organization, 1980).

Many of the instruments that evaluate the QOL were developed in English. However, there is a need to develop instruments to be used in other languages. For achieving this, there are two options: developing a new measurement instrument or adapting an existing one in other language (Guillemin et al., 1993). The cultural adaptation has the advantage of enabling the comparison of results, when applied in countries with different idioms.

In 1990, Jacobson and Newman designed and validated an specific questionnaire for dizziness, the Dizziness Handicap Inventory (DHI), aiming at evaluating the self-perception of the incapacitating effects provoked by dizziness.

The identification of the most affected aspects in these individuals may assist the choice of the most adequate therapy (Yardley, 1994). Furthermore, the DHI has been used as an evaluation method of the otoneurological treatment effects, whether by medication, surgical and/or physical rehabilitation (Jacobson et al., 1991; Perez et al., 2000a; Perez et al., 2000b).

The DHI has been adapted to be used in other idioms (Perez et al., 2000a; Poon et al., 2004), however there is no record of a careful cultural adaptation for the Brazilian Portuguese.

The purposes of this study were to culturally adapt the DHI for application on the Brazilian population, to assess its reproducibility and to describe the results of its application in chronic dizzy patients.

\section{Method}

The study was approved by the Ethics Committee of the Federal University of São Paulo (protocol no. 0766/04). All patients signed the Informed Consent Term.

The cultural adaptation of the DHI followed the stages indicated by Guillemin et al. (1993): translation from English to Portuguese and linguistic adaptation, grammatical and idiomatic equivalence review, cultural adaptation, and evaluation of the reproducibility.

The DHI is composed by 25 questions: seven of them evaluate the physical aspects, nine the emotional aspects, and nine the functional aspects (Jacobson \& Newman, 1990).

Translation from English to Portuguese and the linguistic adaptation

The questionnaire was given to three fluent English teachers, who didn't know each other and didn't know the questionnaire. This procedure was done aiming at generating three independent documents.

The three documents were analyzed by a reviser group constituted by two doctors and a speech-language therapist (all Brazilian with fluent knowledge of English), who reduced the differences found in the translations, choosing the best expressions and words in all questions and adapting the text to the Brazilian cultural knowledge. This stage involved the selection of the best translation for the questions and the 
modification, by approximation, of the more appropriate terms, chosen in order to allow the comprehension by the Brazilian people, constituting thus, a new and unique questionnaire named Brazilian DHI questionnaire.

\section{Grammatical and idiomatic equivalence review}

Next, the Brazilian DHI was given to three different translators, of same linguistic and cultural condition as the first ones. These translators did not know the original text and were required to do a new English version. It was not allowed that these new translators had contact with the original text, written in English, in order to avoid any influence in the translation of words. The three resulting versions were submitted to the appreciation of the reviser group, that created a new English version. This version was compared to the original English text.

Two hundred and fifty (250) patients who went to the ambulatory of the Otoneurology Discipline of the Federal University of São Paulo took part in this research. They presented chronic dizziness complaint (lasting more than or equal to three months) and diagnostic hypothesis of vestibular syndrome. The sample was characterized by individuals with mean age of 61,3 years, minimum age of 14 years and maximum of 91 years. Most of them were female $(74,0 \%)$.

The first 45 patients with chronic dizziness were divided in two groups. The first group (Group 1) was composed by 20 patients who responded the translated DHI in the cultural adaptation stage. The second group (Group 2) was composed by 25 patients who responded the questionnaire in the reproducibility test stage.

\section{Cultural adaptation}

The Brazilian version of the DHI was then applied on the 20 patients of Group 1 . The questions in which the subjects presented comprehension difficulty were listed for posterior analysis and were explained so they could be responded. The questionnaire was applied individually. The questions were formulated orally, always by the same interviewer (ENTERV1), and the "yes", "no" or "sometimes" responses were registered.

The cultural equivalence was established according to the criteria of Guillemin et al. (1993), in which at least $80 \%$ of the individuals shouldn't present any kind of difficulty to respond each formulated question. These questions are then submitted, individually, to a new cultural adaptation process after the modification.

\section{Reproducibility of the questionnaire}

In order to test the reproducibility of the Brazilian DHI, the questionnaire was applied by two different interviewers, INTERV1 and INTERV2, on the 25 patients of Group 2. This procedure was done to enable the comparison of the responses obtained with the same individual with different researchers, therefore allowing the investigation of inter-researchers variations. The patients were interviewed in the same day by INTERV1 and INTERV2. The questionnaire application order by the interviewers was arbitrary.

After 15 days, the same patients were submitted to a new application of the Brazilian DHI by INTERV1. Hence, the intra-researcher variation was observed. This time interval was determined in order to avoid that important variations in the health state of the patients could interfere on the answers.

Application of the Brazilian DHI on the Brazilian population

The Brazilian DHI was applied on a total of 250 patients, including the individuals from Groups 1 and 2 . The responses given by the patients were scored as follows: the affirmative answers (YES) scored 4 points; the negative answers (NO) did not score, the sometimes answers scored 2 points.

The total score as well as the specific scores of each aspect were computed. This way, the higher total score would be 100 points, indicating a maximum damage caused by the dizziness, and the lower, 0 point indicating no damage caused by the dizziness in the patient's life. Accordingly, analyzing each aspect individually, the higher the score the greater the damage caused by the dizziness.

\section{Statistical Analysis}

In order to analyze the inter and intraresearchers differences concerning the total score and the different aspects results during the application of the Brazilian DHI, the non-parametric test of Wilcoxon for two dependent samples was used, $\mathrm{p}<0,05$.

In order to compare the results of the aspects evaluated by the Brazilian DHI, the arithmetic mean of the different aspects was used and the variance 
analysis with repeated measure was applied. When the test was significant $(\mathrm{p}<0,05)$, the multiple comparison analysis was performed using the Bonferroni's method aiming at determining in which pairs the difference was found. The arithmetic mean was used for the comparison of the evaluated aspects due to the different number of questions of each aspect evaluated by the DHI, that is, seven questions of the physical aspect, nine of the functional and nine of the emotional.

With the intention of verifying the possible correlations between the Brazilian DHI scores and the variable "age", the Pearson's correlation coefficient $®$ was used, $p<0,05$. For verifying the association with the variable "gender", the TStudent test was used.

\section{Results}

The first 20 patients who constituted Group 1 answered the Brazilian DHI questionnaire in the cultural adaptation stage. The age of these patients varied from 54 to 91 years, and the mean age was 72,8 years. Eleven individuals were female and nine male. Group 2 was composed by 25 patients who answered the questionnaire in the reproducibility test stage, ranging in aged from 44 to 88 years, with mean age of 66,8 years. Nineteen individuals were female and six male.

The Brazilian DHI obtained after the translation from English to Portuguese and the linguistic adaptation is found in Chart 1.

The English version obtained with the translation of the Brazilian DHI by three translators was compared with the original version of the DHI, and the grammatical and idiomatic equivalence between the two versions were verified.

The Brazilian DHI that was applied individually on patients from Group 1 was largely well comprehended by the subjects; only $15 \%$ of them presented difficulties understanding questions 3 and 6.

The results obtained from the averages of the total scores with the application of the Brazilian DHI by INTERV1 and INTERV2 on patients from Group 2(Table 1) in order to evaluate the inter-researcher reproducibility did not show significant statistical difference $(p=0,418)$. The results obtained from averages of the total scores in the two applications of the Brazilian DHI conducted by INTERV1, on patients from Group 2 (Table 1) in order to investigate the intra-researcher reproducibility did not show significant statistical difference ( $\mathrm{p}=0,244)$.

Comparing the aspects evaluated by the Brazilian DHI in its application on 250 patients, it was observed that the physical aspects of patients with chronic dizziness present higher arithmetic average $(2,09)$, followed by the functional aspects $(1,80)$ and the emotional aspects $(1,54)$, as presented in table 2 .

In the comparison between the aspects evaluated by the Brazilian DHI, the variance analysis with repeated measure revealed significant differences $(\mathrm{p}<0,001)$. The multiple comparisons analysis, done with Bonferroni's test, found significant differences between the physical and emotional aspects $(\mathrm{p}<0,001)$, physical and functional aspects $(\mathrm{p}<0,001)$ and emotional and functional aspects $(\mathrm{p}<0,001)$, as shows figure 1 .

No correlation was verified between the DHI total score and the variable "age". Nevertheless, it was observed a weak correlation between the functional aspect and the age ( $\mathrm{p}=0,046 ; \mathrm{r}=0,127)$. Thus, it was observed that the patients' functional aspects were more damaged as their age increased. No association was verified between the variable "gender" and the total score and each DHI aspect averages. 
01. Olhar para cima piora a sua tontura?

$\operatorname{sim} \square$ não $\square$ às vezes $\square$

02. Você se sente frustrado(a) devido a sua tontura?

03. Você restringe suas viagens de trabalho ou lazer por causa da tontura?

04. Andar pelo corredor de um supermercado piora a sua tontura?

$\begin{array}{ll}\text { 05. Devido a sua tontura, você tem dificuldade ao deitar-se ou levantar-se da cama? } & \text { sim } \square \text { não } \square \text { às vezes } \square\end{array}$

$\operatorname{sim} \square$ não $\square$ às vezes $\square$

06. Sua tontura restringe significativamente sua participação em atividades sociais tais como: sair para jantar, ir ao cinema, dançar ou ir a festas?

07. Devido a sua tontura, você tem dificuldade para ler?

$\operatorname{sim} \square$ não $\square$ às vezes $\square$

$\operatorname{sim} \square$ não $\square$ às vezes $\square$

$\operatorname{sim} \square$ não $\square$ às vezes $\square$

08. Sua tontura piora quando você realiza atividades mais difíceis como esportes, dançar, trabalhar

em atividades domésticas tais como varrer e guardar a louça?

09. Devido a sua tontura, você tem medo de sair de casa sem ter alguém que o acompanhe?

10. Devido a sua tontura, você se sente envergonhado na presença de outras pessoas?

11. Movimentos rápidos da sua cabeça pioram a sua tontura?

12. Devido a sua tontura, você evita lugares altos?

13. Virar-se na cama piora a sua tontura?

$\operatorname{sim} \square$ não $\square$ às vezes $\square$

$\operatorname{sim} \square$ não $\square$ às vezes $\square$

14. Devido a sua tontura, é difícil para você realizar trabalhos domésticos pesados ou cuidar do quintal?

15. Por causa da sua tontura, você teme que as pessoas achem que você está drogado(a) ou bêbado(a)?

16. Devido a sua tontura é difícil para você sair para caminhar sem ajuda?

17. Caminhar na calçada piora a sua tontura?

18. Devido a sua tontura, é difícil para você se concentrar?

19. Devido a sua tontura, é difícil para você andar pela casa no escuro?

20. Devido a sua tontura, você tem medo de ficar em casa sozinho(a)?

21. Devido a sua tontura, você se sente incapacitado?

22. Sua tontura prejudica suas relações com membros de sua família ou amigos?

23. Devido a sua tontura, você está deprimido?

24. Sua tontura interfere em seu trabalho ou responsabilidades em casa?

25. Inclinar-se piora a sua tontura?

$\operatorname{sim} \square \quad$ não $\square$ às vezes $\square$

$\operatorname{sim} \square$ não $\square$ às vezes $\square$

$\operatorname{sim} \square$ não $\square$ às vezes $\square$

$\operatorname{sim} \square$ não $\square$ às vezes $\square$

$\operatorname{sim} \square$ não $\square$ às vezes $\square$

$\operatorname{sim} \square$ não $\square$ às vezes $\square$

$\operatorname{sim} \square$ não $\square$ às vezes $\square$

$\operatorname{sim} \square \quad$ não $\square$ às vezes $\square$

$\operatorname{sim} \square$ não $\square$ às vezes $\square$

$\operatorname{sim} \square$ não $\square$ às vezes $\square$

$\operatorname{sim} \square$ não $\square$ às vezes $\square$

$\operatorname{sim} \square$ não $\square$ às vezes $\square$

$\operatorname{sim} \square$ não $\square$ às vezes $\square$

$\operatorname{sim} \square$ não $\square$ às vezes $\square$

$\operatorname{sim} \square$ não $\square$ às vezes $\square$

$\operatorname{sim} \square$ não $\square$ às vezes $\square$

$\operatorname{sim} \square \quad$ não $\square$ às vezes $\square$

\section{Legend:}

physical aspects (questions 01, 04, 08, 11, 13, 17 and 25)

functional aspects (questions 03, 05, 06, 07, 12, 14, 16, 19 and 24)

emotional aspects (questions 02, 09, 10, 15, 18, 20, 21, 22 and 23)

for each response yeas $=04$ points
The final score is the sum of the points obtained in all aspects.

sometimes $=02$ points

no $=00$ points 
TABLE 1 - Average and distribution of the total scores with the application of the DHI on patients from Group 2, according to interviewer 1 (first and second interviews) and interviewer 2

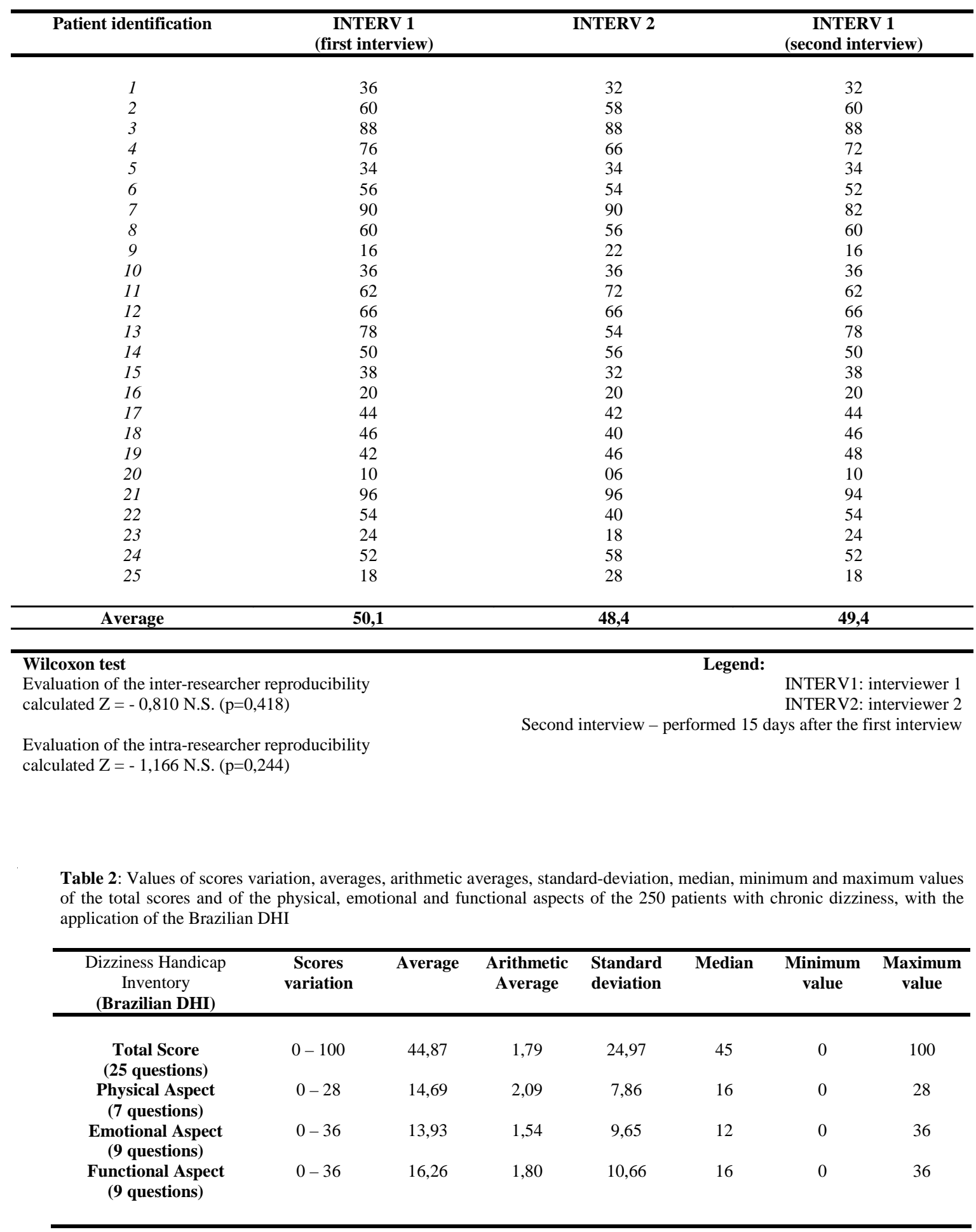


Figure 1 - Graphic representation of the arithmetic averages scores obtained in the physical, emotional and functional aspects with the application of the Brazilian DHI on 250 patients with chronic dizziness

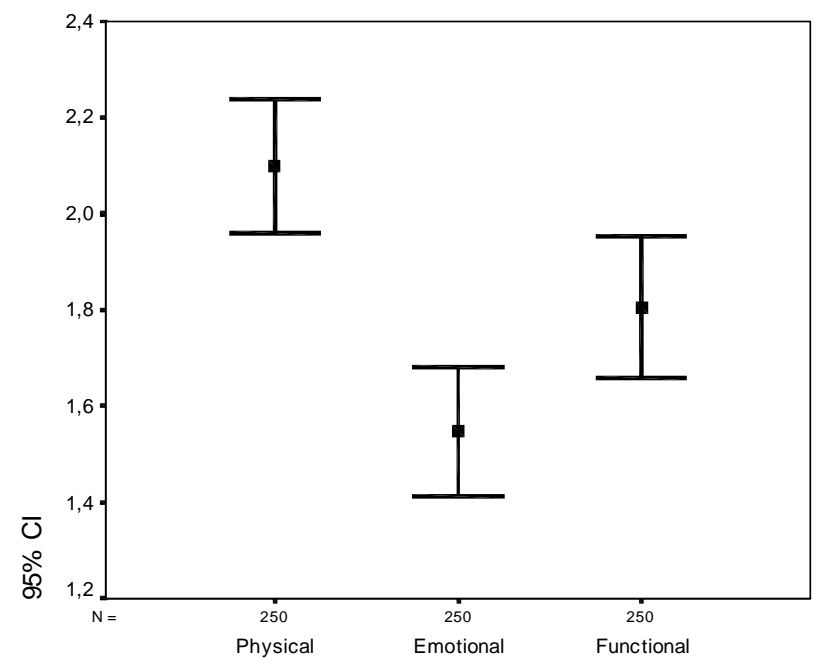

\section{Discussion}

The DHI was the chosen questionnaire for the cultural adaptation to the Brazilian Portuguese because it is a reliable tool used in several studies (Perez et al., 2000b; Gamiz \& Lopez-Escamez, 2004; Ganança et al., 2004; Poon et al., 2004; Cunha et al., 2005; Handa et al., 2005; Gazzola et al., 2006, Segarra-Maegaki \& Taguchi, 2005).

The DHI was developed in an specific cultural environment, the United Stated of America, that is economic, cultural and socially different from other countries, reason why its use with the Brazilian people requires cultural adaptation. Those differences are not solved with a single literal translation; it's necessary to take into consideration the cultural adaptation procedure and the application of the questionnaire in order to determine the equality of metric characteristics between the original version and the translated one (Guillemin et al., 1993).

For the translation and cultural adaptation of the DHI, the stages proposed by Guillemin et al. (1993) were followed; they are internationally accepted and used in countries from the European and American continents for the cultural adaptation of instruments, such as Roland-Morris Questionnaire (Nusbaum et al., 2001), Patient Knowledge Questionnaire (Natour et al., 2002), Disability of the Arm, Shoulder and Hand (Dash)
(Orfale et al., 2005) and Berg Balance Scale (Miyamoto et al., 2004).

At the cultural adaptation stage, the application of the questionnaire on 20 patients with dizziness did not reveal difficulties in the comprehension of the questions. The minimum level required for the questions to be reformulated was not reached. At this stage only three patients presented doubts regarding questions 3 and 6. Question 3 asked whether the patient restricted his work or pleasure trips, and question 6, if the patient restricted his social activities such as going out to dinner, going to parties or to the movies, or going out to dance. These patients referred not being used to doing such activities. The evaluated patients are of low socio-economic level, which can interfere on the performance of certain social, professional and domestic activities. The verb restrict may also have hindered the comprehension, although all patients responded the respective question demonstrating comprehension of the expression or the context used. This number of patients represent $15 \%$ of the total, which is not considered relevant for the modification of the question, or changing some word and/or expression (Guillemin et al., 1993).

The questions were well understood by the evaluated population. This population was composed by patients who looked for a tertiary 
hospital, from different regions of Brazil, suggesting that the cultural adaptation established was adequate to the Brazilian population in general.

After the cultural adaptation, the questionnaire was applied on other 25 patients in order to test the inter and intra-researchers reproducibility. It was observed an inter and intra-researchers reproducibility with very similar values between the scores of physical, emotional and functional aspects and the total score between the two interviews of INTERV1 in Group 2, and also regarding the total scores and the several aspects obtained by INTERV1 and INTERV2 in Group 2. These results agree with the ones obtained by Perez et al. (2000a) who verified the reproducibility of the Spanish version of the DHI.

Regarding the mean age of all studied patients, it was verified that it was high (61,3 years). It is well known that dizziness is more prevalent in elderly individuals who tend to present a poor body balance in comparison to the youngsters. The age related disorders in the systems related to the body balance, the greater possibility of chronicdegenerative diseases and the chronic use of medications, among other factors, may favor the manifestation of the dizziness symptom, or aggravate its intensity, provoking greater physical and functional limitation or increasing the emotional damage in this age group. The prevalence of more aged patients in the studied population may have influenced the higher scores obtained with the application of the Brazilian DHI.

Many of the patients of this study affirmed, when answering the Brazilian DHI, having limitations regarding social activities. These activities were related to the functional aspects of this questionnaire. This results agree with the ones from Yardley and Putman (1992) who described that many patients with dizziness restrict their physical activities, social trips and meetings, aiming at reducing the risk of having those unpleasant symptoms.

The functional aspects investigated by the Brazilian DHI searched the interference of the dizziness on the performance of certain eye, head and body movements, although focusing on the capacity of performing professional, domestic, social and pleasure activities and on the independency for doing tasks such as walking without help and walking at home in the dark. The prejudice of these activities was also studied by Cohen (1994), who observed that patients with vestibular dysfunction present difficulty in performing functional activities that require the rapid movement of the head, such as driving a car, and tasks that imply on the flexion of the trunk and the head, such as putting socks and shoes on.

The functional aspects were the most defeated ones with the increasing age of the patients, probably due to the effects of the vestibular system aging, which may enhance the functional limitations in these patients (Cohen, 1992). Gazzola et al. (2006) found a weak negative correlation statistically significant between the functional aspect of the DHI and the functional balance in a sample of 120 aged individuals with chronic vestibular dysfunction.

The emotional aspects evaluated by the Brazilian DHI were also damaged in the studied patients. These aspects investigated the possible harm caused by the dizziness on the QOL, generating frustration, fear of going out without company or staying home alone, shame of its clinical manifestations, worries about the selfimage, concentration disorder, incapacity sensation, familiar or social relationship alteration, and depression. This result agrees with Paiva and Kuhn (2004) who verified that patients with complaints of vertigo present concomitant psychological symptoms in 56,38\% of the cases, being the anguish the most prevalent one $(47,38 \%)$, followed by anxiety, fear, depression and memory disorders, stressing the relation between the vestibular disorder and emotional alterations.

The physical aspects investigated by the Brazilian DHI, although evaluated by a smaller number of questions than the other aspects of this questionnaire, were the ones that presented higher arithmetic averages scores. Fielder et al. (1996) also verified that for either men or women, the performance of physical functions was significantly more affected by the vertigo's effects than the other aspects evaluated by the DHI. The Brazilian DHI physical aspects evaluated the relation between the manifestation and/or the worsening of the symptom dizziness and the eye and body movements. The manifestation of dizziness in certain positions or head movements is very common and may occur, for example, in patients with benign paroxistic positional vertigo, the most common vestibulopathy (Ganança \& Caovilla, 1998a). Other postural vertigos may be manifested with dizziness when bending the body. Visual stimuli (supermarket row, obstacles in the sidewalk, pedestrians movements) may provoke or worsen the dizziness and are also investigated by the Brazilian DHI. 
The Brazilian DHI can be applied in our environment as an instrument that allows the evaluation of the damages caused by the dizziness in patients with vestibulopathy QOL, and also as a clinical evolution follow up method that verifies the therapeutic effect obtained, either due to the rehabilitation treatment, or to medications and/or to surgeries.

\section{References}

COHEN, H. Vestibular rehabilitation reduces functional disability. Otolaryngol. Head Neck Surg., Rochester (US), v. 107, n. 5, p. 638-643, nov. 1992.

COHEN, H. Vestibular rehabilitation improves daily life function. Am. J. Occup. Ther, Rockville (US), v. 48, n. 10, p. 919-925, oct. 1994.

CUNHA, F.; SETTANNI, F. A. P.; GANANÇA, F. F. What is the effect of dizziness on the quality of life for patients with Meniere's disease? R. Laryngol. Otol. Rhinol., Bordeaux (FR), v. 126, n. 3, p. 155-158, dez. 2005.

ENLOE, L. J.; SHIELDS, R. K. Evaluation of health related quality of life in individuals with vestibular disease using disease - specific and general outcome measures. Phys. Ther., New York (US), v. 77, n. 9, p. 890-903, sep. 1997.

FIELDER, H.; DENHOLM, S. W.; LYONS, R. A.; FIELDER, C. P. Measurement of health status in patients with vertigo. Clin. Otolaryngol., Philadelphia (US), v. 21, n. 2, p. 124-126, apr. 1996.

GAMIZ, M. J.; LOPEZ-ESCAMEZ, J. A. Health-related quality of life in patients over sixty years old with benign paroxysmal positional vertigo. Gerontol., Basel $(\mathrm{CH})$, v. 50, n. 2, p. 82-86, mar.-apr. 2004.

GANANÇA, M. M.; CAOVILLA, H. H. Desequilíbrio e reequilíbrio. In: GANANÇA, M. M. (Ed.). Vertigem tem cura? São Paulo: Lemos, 1998a. p. 13-19.

GANANÇA, M. M.; CAOVILLA, H. H. A vertigem e sintomas associados. In: GANANÇA, M. M.; VIEIRA, R. M.; CAOVILlA, H. H. Princípios de Otoneurologia. São Paulo: Atheneu, 1998b. p. 3-5. (Série distúrbios de comunicação humana).

GANANÇA, M. M.; CAOVILLA, H. H.; MUNHOZ, M. S. L.; SILVA, M. L. G.; KUHN, A. M. B.; GANANÇA, C. F. Vertigem Psicossomática. In: SILVA, M. L. G.; MUNHOZ, M. S. L.; GANANÇA, M. M.; CAOVILLA, H. H. Quadros clínicos otoneurológicos mais comuns. São Paulo: Atheneu, 2000. p. 145-151. (Série otoneurológica, v. 3).

GANANÇA, F. F.; PERRACINI, M. R.; GANANÇA, C. F. Reabilitação dos distúrbios do equilíbrio corporal. In: GANANÇA, M. M. (Ed.). Vertigem: abordagens diagnósticas e terapêuticas. São Paulo: Lemos, 2002. p. 16. manual

\section{Conclusion}

The Brazilian DHI was reliable for the assessment of the impact of dizziness on the QOL. Patients with chronic dizziness or with diagnostic hypothesis of vestibular syndrome present weakening in their QOL due to this symptom, verified with the application of the Brazilian DHI. The physical aspects were the most defeated ones, followed, in decreasing order, by the functional and the emotional aspects. The functional aspects were more defeated in older patients.

GANANCA, F. F.; CASTRO, A. S. O.; BRANCO, F. C. A.; NATOUR, J. Interferência da tontura na qualidade de vida de pacientes com síndrome vestibular periférica. $R$. Bras. Otorrinolaringol., Rio de Janeiro (RJ), v. 70, n. 1, p. 94101, jan. 2004.

GAZZOLA, J. M. Fatores associados ao equilíbrio funcional de idosos com disfunção vestibular crônica. R. Bras. Otorrinolaringol., Rio de Janeiro (RJ), v. 72, n. 5, p. 683690, set.-out. 2006.

GUILLEMIN, F.; BOMBARDIER, C.; BEATON, D. Crosscultural adaptation of health-related quality of life measures: literature review and proposed guidelines. J. Clin. Epidemiol., Oxford (GB), v. 46, n. 12, p. 1417-1432, dec. 1993.

HANDA, P. R.; KUHN, A. M. B.; CUNHA, F.; DORIGUETO, R. S.; GANANÇA, F. F. Qualidade de vida em pacientes com vertigem posicional paraxística benigna e/ou doença de Ménière. R. Bras. Otorrinolaringol., Rio de Janeiro (RJ), v. 71, n. 6, p. 776-782, dez. 2005.

JACOBSON, G. P.; NEWMAN, C. W. The development of the dizziness handicap inventory. Arch. Otolaryngol. Head Neck Surg., Chicago (US), v. 116, n. 4, p. 424-427, apr. 1990.

JACOBSON, G. P.; NEWMAN, C. W.; HUNTER, L.; BALZER, G. K. Balance function test correlates of the dizziness handicap inventory. J. Am. Acad. Audiol., Hamilton (CA), v. 2, n. 4, p. 253-260, oct. 1991.

MIYAMOTO, S. T.; LOMBARDI JR, I.; BERG, K. O.; RAMOS, L. R.; NATOUR, J. Brazilian version of the Berg balance scale. Braz. J. Med. Biol. Res., Ribeirão Preto, v. 37, n. 9, p. 1411-1421, set. 2004.

NATOUR, J.; SIMÕES, M. F. J.; ASSIS, M. R.; TOFFOLO, S. Brasil "Patient Knowledge Questionnaire"(PKQ) e avaliação do conhecimento sobre a doença de pacientes com artrite reumatóide. R. Bras. Reumatol., Campinas, v. 42, n. 1, p. 32-34, jan.-fev. 2002.

NUSBAUM. L.; NATOUR, J.; FERRAZ, M. B.; GOLDENBERG, J. Translation, adaptation and validation of the Roland-Morris questionnaire - Brazil RolandMorris. Braz. J. Med. Biol. Res., Ribeirão Preto, v. 34, n. 2, p. 203-210, feb. 2001. 
ORFALE, A. G. Translation into Brazilian Portuguese, cultural adaptation and evaluation of the reliability of the disabilities of the arm, shoulder and hand questionnaire. Braz. J. Med. Biol. Res., Ribeirão Preto, v. 38, n. 2, p. 293-302, feb. 2005.

PAIVA, A. D.; KUHN, A. M. B. Psychological symptoms associated to dizziness complaint in neurootological patients of Universidade Federal de São Paulo - Escola Paulista de Medicina. R. Bras. Otorrinolaringol., Rio de Janeiro, v. 70, n. 4, p. 512-515, ago. 2004.

PEREZ, N.; GARMENDIA, I.; MARTIN, E.; GARCIATAPIA, R. Cultural adaptation of 2 questionnaires for health measurement in patients with vertigo. Acta Otorrinolaringol. Esp., Madri (ES), v. 51, n. 7, p. 572-580, oct. 2000a.

PEREZ, N.; GARMENDIA, I.; MARTIN, E.; BOLEAS, M. S.; GARCIA-TAPIA, R. Health measurement instruments in patients with vertigo. Acta Otorrinolaringol. Esp., Madri (ES), v. 51, n. 8, p. 677-685, nov.-dez. 2000 b.
POON, D. M.; CHOW, L. C.; AU, D. K.; HUI, Y.; LEUNG, M. C. Translation of the dizziness handicap inventory into Chinese, validation of it, and evaluation of the quality of life of patients with chronic dizziness. Ann. Otol. Rhinol. Laryngol., St. Louis (US), v. 113, n. 12, p. 1006-1011, dec. 2004.

SEGARRA-MAEGAKI, J. A.; TAGUCHI, C. K. Study about the benefits of vestibular rehabilitation in peripheral vestibular disorders. Pró-Fono R. Atual. Cient., Barueri (SP), v. 17, n. 1, p. 3-10, jan.-abr. 2005.

YARDLEY, L.; PUTMAN, J. Quantitative analysis of factors contributing to handicap and distress in vertiginous patients: a questionnaire study. Clin. Otolaryngol., Philadelphia (US), v. 17, n. 3, p. 231-236, jun. 1992.

YARDLEY, L. Contribution of symptoms and beliefs to handicap in people with vertigo: a longitudinal study. $B r$. J. Clin. Psychol., Letchworth Herts (GB), v. 33, n. 1, p. 101-113, feb. 1994. Pt. 1.

WORLD HEALTH ORGANIZATION. International classification of impairments, disabilities and handicaps: a manual of classification relating to the consequences of disease, published in accordance with resolution WHA29.35 of the Twenty-ninth World Health Assembly, may 1976. Geneva: World Health Organization, 1980. 205 p. 